\title{
Taking Preprimary Programs to Scale in Developing Countries: Multi-source Evidence to Improve Primary School Completion Rates
}

\author{
Luis Crouch $^{1}$ D Katherine King ${ }^{1} \cdot$ Anna Olefir $^{2} \cdot$ Hiroshi Saeki $^{2}$. \\ Tanya Savrimootoo ${ }^{2}$
}

Published online: 3 August 2020

(C) The Author(s) 2020, corrected publication 2020

\begin{abstract}
The paper argues that in many developing countries there is a set of linked symptoms in education systems that cohere into what we call a weak foundations syndrome. Multi-source evidence is presented to illustrate how weak foundations through the early years of schooling lead to low primary school completion. Symptoms of the syndrome include (1) low access, use, and quality in preprimary programs; (2) permanently high apparent rate of intake (above 100\%) into grade 1; (3) over-enrollment bulge, in the early grades, as well as formal and informal grade repetition through primary school; (4) apparent large enrollment drop-off between grades 1 and 2. Small stories for Burundi, Madagascar, and Ethiopia are presented to illustrate the syndrome. These cases also identify how countries and international organizations are starting to address the issues. An interesting aspect of the findings is the data that show parents' support for preprimary education by enrolling their children earlier than the normative age for grade 1 .
\end{abstract}

Keywords Preprimary · Low- and middle-income countries · Foundational skills · Grade repetition · Primary school completion

\section{Résumé}

Cet article soutient que dans de nombreux pays en développement il existe un ensemble de symptômes reliés dans les systèmes d'éducation et qui forment ce que nous appelons un syndrome de fondations faibles. Des preuves provenant de sources multiples sont présentées pour illustrer comment des fondations faibles au cours des premières années de la scolarité conduisent à un faible taux d'achèvement de la scolarité primaire. Les symptômes de ce syndrome comprennent: (1) une faiblesse d'accès,

\footnotetext{
Luis Crouch

lcrouch@rti.org

1 RTI International, 13th St NW, Washington, DC 20005, USA

2 World Bank, H Street NW, Washington, DC 20433, USA
} 
d'utilisation et de qualité des programmes préscolaires; (2) un taux d'admission en $1^{\text {re }}$ année constamment apparemment élevé (supérieur à 100\%); (3) une explosion des inscriptions dans les premières années, ainsi qu'un redoublement formel et informel tout au long de l'école primaire; (4) une chute apparemment importante des effectifs entre la $1^{\text {re }}$ et la $2^{\mathrm{e}}$ année. Des petits récits sont présentés pour illustrer ce syndrome au Burundi, à Madagascar et en Éthiopie. Ces cas montrent aussi comment les pays et les organisations internationales commencent à aborder ces problèmes. Un aspect intéressant de ces résultats concerne des données révélant le soutien des parents à l'éducation préscolaire par l'inscription de leurs enfants plus tôt qu'à l'âge normatif pour la $1^{\text {re }}$ année.

\section{Resumen}

Este estudio sostiene que en muchos países en vías de desarrollo existe una serie de síntomas comunes en los sistemas de educación que son coherentes con lo que se conoce como un síndrome de base escolar débil. Se presenta evidencia de fuentes múltiples para ilustrar cómo la debilidad en la base de escolaridad en los primeros años conlleva a una tasa baja de finalización de la escuela primaria. Los síntomas del síndrome incluyen: (1) bajo acceso, uso y calidad de programas de preescolar; (2) alta tasa aparente de ingreso (cercana al 100\%) al primer año; (3) exceso de matrículas en los primeros años, así como repetición formal e informal de grados escolares durante los años de primaria; (4) alta disminución aparente de matrículas entre los años 1 y 2. Se presentan historias cortas de Burundi, Madagascar y Etiopía para ilustrar este síndrome. Estos casos también muestran cómo países y organizaciones internacionales han comenzado a abordar estos problemas. Un aspecto interesante de estos hallazgos ha sido información que muestra el apoyo de padres a la educación preescolar al matricular a sus niños antes de la edad obligatoria para el primer año de primaria.

\section{Introduction}

The provision of preprimary education programs has grown substantially in the past two decades. Nevertheless, in the last few years, the percentage of children accessing these services in the poorest 40 countries in the world, for which there is available data, has averaged only about $17 \%$ and, in the next-poorest 40 countries, it is only $37 \% .{ }^{1}$ At the same time, availability of primary schooling has been reported as $110 \%$ in the poorest 40 countries. This latter percentage is a result of counts that include children who enroll early in primary school, especially if no preprimary programs are available to families. Children are also be likely to repeat an early primary grade. At the same time, only $69 \%$ of children complete primary school in these countries. Enrollment figures of $110 \%$ for primary school that only produce only a $69 \%$ completion rate is a significant financial loss in educational investment but, more importantly, there are lost opportunities for many

\footnotetext{
1 Data in this paragraph were sourced from World Bank-EdStats: https://databank.worldbank.org/repor ts.aspx ?source $=$ Education $\% 20$ Statistics.
} 
children to achieve their potential. This paper explores the influencing factors that produce this situation. It illustrates how weak foundations for learning through the early years of school as well as access to preprimary programs lead to low primary school completion. Although these analyses do not make causal claims for connections between the influencing factors discussed that produce poorer educational outcomes, such linkages are unlikely to be mere coincidence.

This paper will demonstrate that there is a set of symptoms that we call a weak foundations syndrome which is apparent in some 30-50 mostly low- and lower-middle-income countries. A more throughout description of the syndrome is offered below. For now, "weak foundations" refers to access to and/or quality or preprimary school and low quality in the first few grades of primary school as signaled by weak student flow through the grades. While there are many good reasons to expand provision of preprimary education, cautions are often expressed, even among advocates. The caution usually comes in the form of "... but let's not allow preprimary to suffer the drops in quality that took place when primary education was universalized starting in the mid-1990s," when the elimination of school fees in a number of East African countries occurred. In educational systems in Africa that had early and mass primary school expansion, perceptions about drops in education quality that accompanied such universalization have been around for at least 70 years, if not more (see Crouch and Vinjevold 2006). Yet, very few of these comments consider that even if learning per child in school has gone down, there are now more children who have access to the education system and so learning per child in the population as a whole may have increased.

There have been few research studies that have rigorously examined the effects of the mass expansion of education on educational quality or on children's learning and development of fundamental skills. Exceptions include the following studies. Taylor and Spaull (2015) used data from two consecutive waves of the learning assessments from the Southern and Eastern Africa Consortium for Monitoring Educational Quality (SACMEQ) and data on primary school completion to argue that “...in all countries there was greater access to learning in 2007 than in 2000. These improvements in access to learning especially benefited girls and children from poor households" (p. 47). Le Nestour and Sandefur (2020), using household survey data from a number of studies that included simple cognitive assessments, conclude that while overall educational quality seems to have dropped in Africa, “... we find little evidence that rapid expansions of school access were accompanied by faster reductions in measured quality" (p. 1). Crouch and Vinjevold (2006) also touch upon these issues. While these two or three studies did not indicate drops in quality, there remain significant concerns about low levels of learning, especially in the foundation years of education in many lowincome countries. This makes it important, through current and future efforts, to measure and raise educational quality. 


\section{The Syndrome Defined}

There are four inter-related factors that interact with each other to produce weak foundations in children's early years education. These factors can be associated with low levels of learning and low completion of the primary school cycle and are present in some 30-40 countries, usually quite poor countries, although not the poorest in the world.

We summarize four published papers in which specific aspects of this syndrome have been analyzed in detail using a variety of methods. The idea that there is an identifiable syndrome pertaining to problems in the foundation years of education was proposed by Crouch and Merseth (2017) and then re-explored, re-analyzed. These ideas were applied in Bashir et al. (2018) to generate further insights into this syndrome and to make policy recommendations. This syndrome is not common across all countries and different countries may show a somewhat different mix of symptoms. The following symptoms have been identified (Crouch and Merseth 2017):

1. Low rates of enrollment in preprimary programs The low rate can be around $25 \%$ of the eligible age population of children, although in many countries this rate is increasing. The causes are usually a lack of physical availability (including distance) or cost.

2. Extremely high rates of apparent intake in grade 1 This rate can be about $125 \%$ for the eligible age population. Sometimes, this situation has been ongoing for decades when, in actuality, it is not possible, even though it is reported and published.

3. Large over-enrollment bulge in grades 1 and 2 of primary school In many countries, enrollment can be more than $50 \%$ larger than the population of children who are eligible by age to be enrolled and, in some countries, it is double what it should be.

4. Sharp drop-off in enrollment from grade 1 and grade 2 Enrollment in grade 2 in many countries is around $70-80 \%$ of the grade 1 enrollment yet, nonetheless, it is still larger than the eligible age population. This is often misconstrued as dropout from grade 1 to grade 2 .

Crouch and Merseth (2017) and Bashir et al. (2018) illustrated statistically that these four symptoms coalesce into a pattern, which is described in this paper as a syndrome. In Fig. 1, the overall syndrome is presented diagrammatically and integrates other contextual factors to illustrate actionable pathways. The four components of the weak education foundations syndrome are shown in bolded boxes. Solid lines connecting the various boxes are connections that are discussed in this paper, drawing on four previously published articles. The boxes with the thin, dashed edges are contributing factors or consequences. The dashed lines are relationships that are either documented in other literature or are being currently researched. Because there are likely to be other important and fundamental influencing factors, no claims of causality in the chains of connections described are made. 


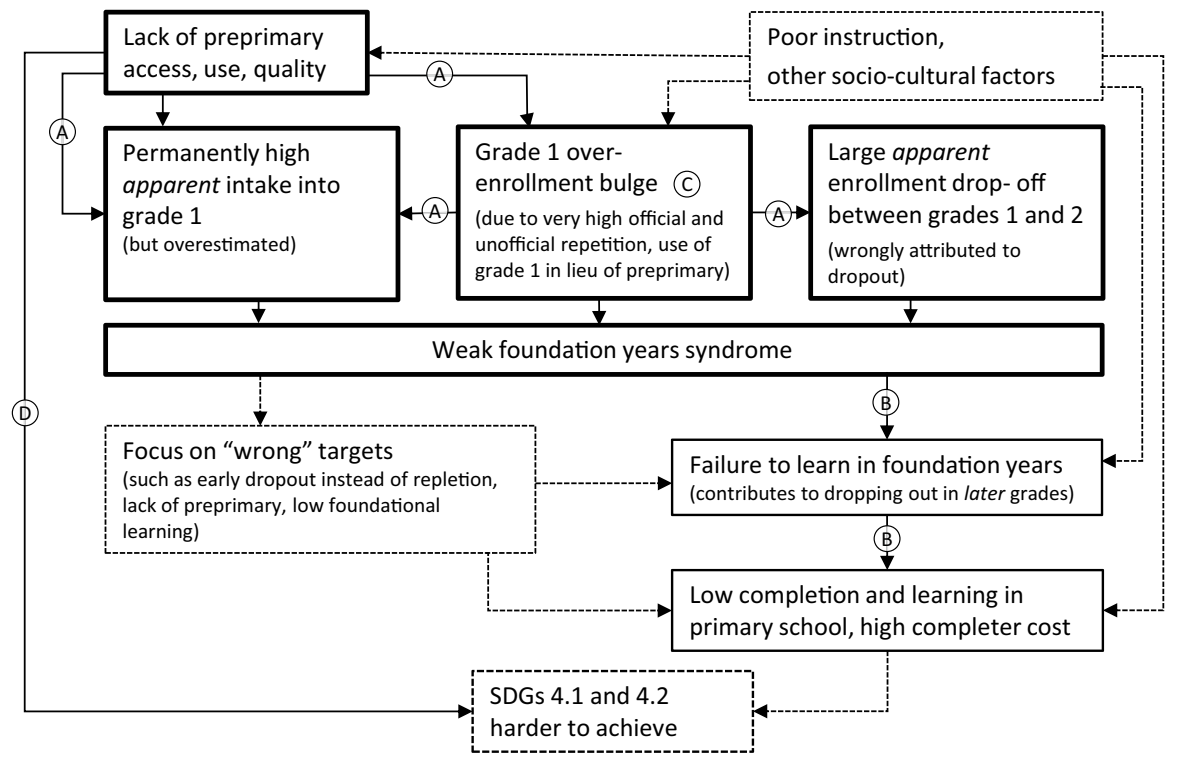

Fig. 1 Weak educational foundations syndrome. Source: authors

\section{Primary School Completion}

This section discusses pathways, identified as B, connecting elements of the model in Fig. 1. Other than access to school, one of the most important and most-watched global indicators of the strength of a schooling system in low-income or lower-middle-income countries is the primary school completion rate. This is the proportion of children in a population age cohort who complete primary school. UN Sustainable Development Goal 4.1 states that countries should, “... By 2030, ensure that all girls and boys complete free, equitable and quality primary ... education" (United Nations 2016, p. 19/62).

The bar chart presented in Fig. 2, as also reported in Crouch et al. (2020), presents the Gross Enrollment Rate (GER) in primary school for five countries (Burindi, Ethiopia, Madagascar, Malawi, and Uganda) for two time periods the most recent 5 years and the previous 5 years), as well as school completion rates for the same time periods. GER is the number of students enrolled as a percentage of the official school-age population. Higher completion rates mean lower student dropout across the primary school years for the eligible-age population. At the top of Fig. 2, ratios of completion in relation to enrollment are presented. Over the last 10 years, ratios of school completion to enrollment are about 50\% (e.g., 0.58, 0.54). Furthermore, we know from other studies that, except for a handful of very poor countries, all children enrolled in grade 1 at some point (Global Partnership for Education 2012). A key point is that these ratios, well below $100 \%$, reflect the impact of grade repetition and dropout from school. This highlights considerable inefficiency (about $50 \%$ ) in the enrollment flows in the educational systems of these countries. 


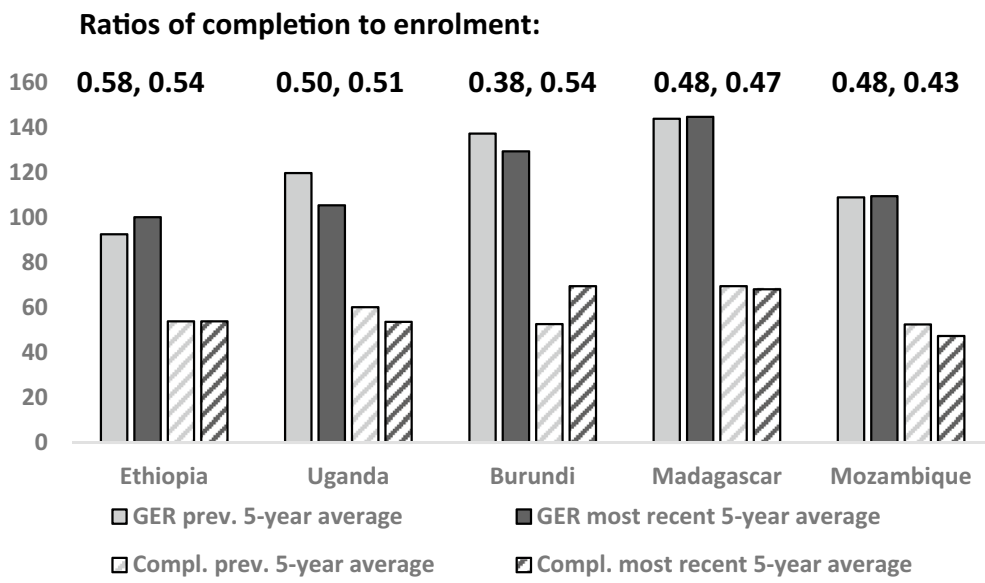

Fig. 2 Low school completion efficiency in selected countries. (Source: Crouch et al. 2020)

Spending on education does not predict school completion very well. Crouch and Merseth (2017) showed in their analyses that a reasonable education expenditure variable was not statistically significant in explaining school completion, while a composite variable of the four factors signaling "weak education foundations" explained $34 \%$ of the variance in school completion and was highly statistically significant. Aside from these four factors, there may be other factors not included in the analyses by Crouch and Merseth (2017) that could also explain low completion (e.g., for example, low quality of teaching in the foundation years of education).

\section{Learning Crisis}

This section discusses pathways, identified as B, connecting elements of the model in Fig. 1. In international agencies and in the developing world, the term "learning crisis" has gained considerable currency in recent years. An example of the available evidence on children's early school learning identifies the nature of this concern. The findings of the Early Grade Reading Assessment reported in 2015 showed that in a range of mostly low-income and middle-income countries, the percentage of children who could not read a single word in a short passage of connected text in grade 2 (approximately 7 years of age) was about 50\% (Gove et al. 2015).

A more recent compilation shows an average of $44 \%$ non-readers across a similar range of countries (see Early Grade Reading Barometer ${ }^{2}$ ). In OECD countries, this percentage would typically be close to $0 \%$. The World Bank (2019) estimates that $53 \%$ of children in low- and lower-middle-income countries are in "learning poverty" because they are not able to read even a simple passage proficiently at age 10. The World Bank report notes that in the 20 countries experiencing this issue in its most acute form, and in the 20 experiencing this in the least acute form, the

$\overline{2}$ Early Grade Reading Barometer: https://earlygradereadingbarometer.org/. 


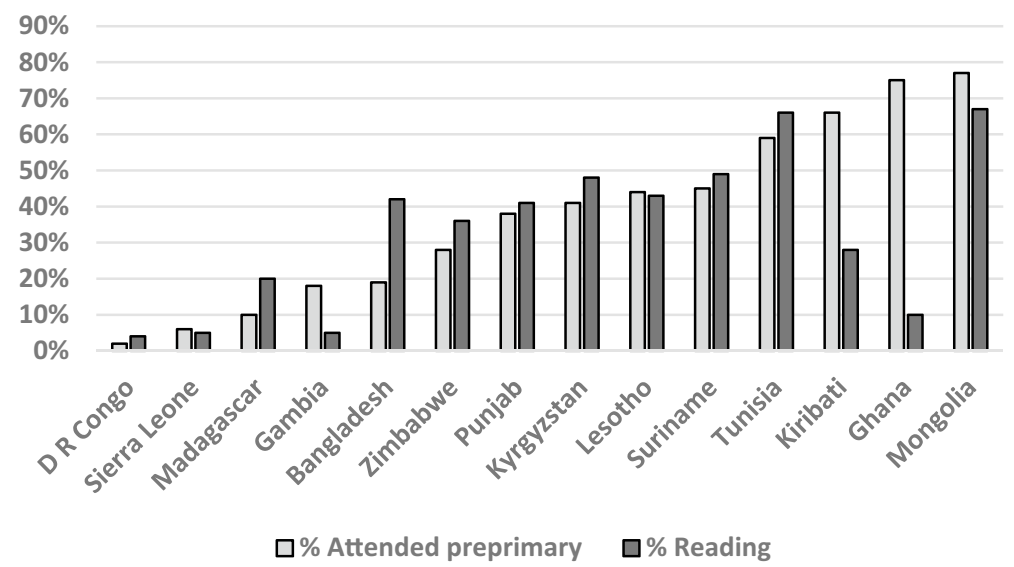

Fig. 3 Preprimary attendance and foundational reading in selected countries. (Source: Special UNICEF tabulation)

percentages are $86 \%$ and $3 \%$, respectively, on average, representing a huge range of global inequality. The Peoples Action for Learning Network (PAL Network ${ }^{3}$ ) who are the creators and managers of "Citizen-Led Assessments," estimate that in a range of countries similar to that in the UNICEF data and the EGRA data cited above, the percentage of grade 3 children who cannot read a grade 2 text is $70 \%$. In short, it does not seem overwrought to label this as a crisis when it is a problematic issue confronted by only $3 \%$ of children in the (mostly) rich countries but confronted by $86 \%$ of children in mostly very poor countries (numbers are not population-weighted to draw attention to the fact that the policy unit in question is the country).

Figure 3 shows the relationship between two issues identified in the weak education foundations syndrome. This figure presents the percentages of children attending preprimary programs between ages 3-5 years and the percentage of children able to read, at 8-10 years, across 14 countries. The correlation between these two variables across these countries identified in Fig. 3 is 0.55, except for Ghana which may reflect measurement problems in the data. When Ghana is excluded as an outlier (it is more than 3 standard deviations away from what one would expect), because its children read at a lower level than one would think given its high preprimary attendance, the correlation is 0.8 . This is as strong a correlation as one could ever identify in such cross-national studies. On average, $62 \%$ of children ages 8-10 (e.g., likely in Grades 3 and 4) are non-readers, and $67 \%$ have not attended a preprimary program. In short, children in countries with low use of pre-primary are also, strongly, non-readers in early primary. Unfortunately, data could not be found for all of these UNICEF countries corresponding to the countries "learning poverty" data of the World Bank (2019). Using the World Bank's measure of learning poverty at age 10

\footnotetext{
${ }^{3}$ PAL network: https://palnetwork.org/wp-content/uploads/2017/11/2017_COMMS_InformationBrie f_CLA4PagerSDG4.1.1_VO2_EN.pdf.
} 
(approximately grade 4) the correlation between learning poverty and the UNICEF data on pre-primary attendance was -0.63 (negative because high learning poverty is a "bad"). In other words, the factors in weak foundations syndrome are strongly correlated with each other and with later reading performance. These associations align with theories of human capital development that suggest that early acquisition of skills enables later acquisition of skills (Cunha and Heckman 2007). What learning occurs in the foundation years of education is strongly associated with what happens late in the primary school cycle, both in terms of completion and of learning.

\section{Hidden Repetition: A Crucial Connector}

This section discusses pathways, identified as A, connecting elements of the model in Fig. 1. A critical factor connecting low learning in the foundation years to later outcomes, such as low school completion and low levels of learning at the end of primary, is hidden repetition. Crouch and Merseth (2017) calculated that, in countries experiencing the worst levels of the weak foundation years syndrome, the proportion of enrollment to population of the right age, in grade 1, was 1.50. For grade 2, relative to the population of the correct age it is 1.28 . This means $50 \%$ overenrollment in Grade 1 and 28\% over-enrollment in Grade 2. Many analysts conclude that this is due to either late or early entry. But this cannot be unless the early or late entry is also accompanied by repetition. If a child enters early but does not repeat, she will not show up again next year. Similarly, for a child who enrolls late, this will not bulk up the total enrollment, because late-entering children would be missing from enrollment counts at the age at which they should have entered. The argument is that late or early entry does not bulk up enrollment numbers permanently and, yet, this bulge in the relevant countries has existed for at least a decade and a half, or more. Only repetition can create a permanent, ongoing enrollment bulge. Yet, officially reported repetition in the countries with the worst levels of weak foundations syndrome, in the first two grades, is only $15 \%$ and $12 \%$ which is not consistent with a long-term bulge of $50 \%$ and $28 \%$ respectively.

Weatherholt et al. (2019) reported field research, similar to that carried out in Latin America, in earlier decades as summarized in Crouch and Merseth (2017). The research, conducted in Uganda in 2018, reported that teachers and caregivers reported repetition for their children to be about four times greater than officially reported by schools to the Ministry. The use of grade 1 by parents, teachers, and schools, as make-do preprimary experiences results in underreported or unofficial repetition, larger class sizes, age heterogeneity, and (more speculatively) some stigmatization for children as a result of repeating.

In Crouch et al. (2020), a simple simulation model similar to those used in earlier studies in Latin America was applied to data from five African countries (Burindi, Ethiopia, Madagascar, Malawi, and Uganda) that show a strong case of the weak education foundations syndrome. The method compared the number of students by grade and age, in two consecutive years, to explore where children who had "disappeared" between grades 1 and 2 could have gone. It is highly unlikely that the children could have dropped out because even by grade 3 there are more children, or 
just as many children, enrolled in grade 3, as there are in the population age cohort for that grade. Crouch et al. (2020) calculated that the unofficial or actual repetition rate in those countries averaged $40 \%$, compared to the official average of $18 \%$. This research also found an estimated rate of intake into grade 1 that was much lower and reasonable, at $103 \%$ than he officially reported average rate of intake which is an unlikely and unsustainable $150 \%$.

It is important to note that the repetition of a school grade does not necessarily mean improvements in learning and achievement (Gibbs and Heaton 2014; Sabates et al. 2013; Branson et al. 2013; N'tchougan-Sonou 2001; Smith 1989; Randall and Anderson 2015; UNESCO IIEP 2006; Bernard et al. 2007; Amadio 1996). Thus, all the more reason to think that the high informal repetition in the early grades and the consequent early grades enrollment bulge are not only associated with lower completion in a statistical sense but also may not be helping with early learning.

\section{Availability of Preprimary Programs}

This section discusses pathways, identified as A and D, connecting elements of the model in Fig. 1. The unavailability of preprimary programs is associated with the other elements of the weak foundations syndrome. On average, the correlation between preprimary availability and the other three elements of the weak foundations syndrome is 0.30 (Crouch and Merseth 2017, p. 182). This is a statistically and substantive correlation for cross-national data. Similarly, using cross-national data, King et al. (2020) found evidence that parents "vote with their feet" by enrolling their children in grade 1, instead of preprimary, when the availability of the latter is not yet high.

However, cross national correlations are not as informative as more detailed country-specific analyses such as Weatherholt et al. (2019), which undertook a random sample survey of schools and students, and their parents and teachers, in Uganda. Studies such as this one in Uganda were carried out in Latin America in the 1980s and early 1990s when that continent was facing many of these symptoms. This study in Uganda explored perceptions by parents and teachers about the level of grade repetition of their children, as opposed to what was reported by the schools to the Ministry of Education, based on school records. The study also researched several other factors related to preprimary attendance and repetition in grade 1. It is important to note that in Uganda grade 1 is mostly public and free, though there are some associated costs, while preprimary is entirely private or communitarian and not at all free. As far as we know, this is the only study in Africa comparing parent and teacher repetition perceptions with school repetition records and taking the availability of preprimary schooling and other contextual factors into account (at least in the last few decades). The findings are statistically strong and substantively significant, and line up with what had been noted in Latin America in earlier decades (see Schiefelbein 1975; Schiefelbein and Wolff 1993; Klein and Costa 1991; Cuadra 1991; Crouch 1991; Fletcher and Ribeiro 1989; Ribeiro 1991; Gargiulo and Crouch 1994). Thus, the findings are worth summarizing here and the study may be worth repeating in other countries with the weak foundations syndrome. 
The study by Weatherholt et al. (2019) reported (among other findings):

- $34 \%$ of grade 1 children had attended some form of preschool, which is much higher than the officially reported 14\%, in line with King et al. (2020).

- $52 \%$ of caregivers and $41 \%$ of teachers reported that the grade 1 children linked to them in the survey had repeated, whereas the official report was only $11 \%$.

- $62 \%$ of parents who did not send their children to preprimary reported that finances were the main reason not to do so.

- $56 \%$ of parents who sent their children to grade 1 earlier than the official starting age did so in full expectation that they might repeat or learn less.

- Teachers expected $41 \%$ of the children in their grade 1 class to repeat.

- Preprimary attendance was highly protective against repetition: $63 \%$ of children without preprimary attendance repeated, but of those who had attended, only $29 \%$ (though still a huge number) repeated. This held true despite trying various control variables such as SES, location, and gender.

The picture that emerges is one where there is considerable expected repetition because many parents find preprimary options unaffordable; children enroll earlier than is official policy and earlier than children who might have attended preprimary; and children then repeat. And note that, partly as a consequence of these weak foundations, Uganda's primary school completion rate is low. Completion has been more or less stuck at a low point for a long time and is very expensively produced, in terms of years of enrollment effort for every completer (see Crouch et al. 2020).

\section{Country Descriptions of the Syndrome}

Burundi, Madagascar, and Ethiopia are presented as example "stories" of the weak foundations syndrome and the relationships between over-enrollment and repetition in the early grades, inappropriate quality or lack of preprimary access, and low primary school completion. The cases illustrate the symptoms and syndrome in a "real world" context, but, more importantly, they help to show how countries and international organizations are starting to address the issues. The three case studies summarize and borrow liberally from a paper by Crouch et al. (2020) in the journal Prospects. The case studies suggest that under-spending on preprimary could be resulting in over-spending, relatively speaking, on primary education. The conclusions to this paper (next section) suggest ways to improve upon this situation.

\section{Burundi}

Under its own impulse, but also with the opportunities and focus of the Education for All and Millennium Development Goals, Burundi eliminated primary school fees in 2005. This led to an immediate jump in enrollment. Gross Enrollment Ratios (GERs) went from $81 \%$ in 2005 to $103 \%$ in 2006 and stayed elevated (121\% in 2018). But restricted access to good and sufficient preprimary partly 
explains lack of preparation for grade 1. Preprimary is not mandatory, largely because of insufficient classrooms and other provisions. In 2017, 1252 preschools took in about 94,900 students or only around $25 \%$ of the size of a population cohort of the right age for school entry. In 2017, in comparison, grade 1 took in 564,270 children. Simultaneously, the population cohort of school entry age was only approximately 390,000 , for a grade 1 over-enrollment bulge of $45 \%$. Due to so much repeating in the foundation grades, Burundi needs to have a GER of about $120 \%$ just to keep a completion rate for primary school of about $70 \%$, suggesting a low efficiency of about 0.54 (70/120). Partly because of the over-enrollment bulge and the low efficiency, Burundi has to spend about $47 \%$ of its education budget on primary education, whereas other low- and lower-middle-income countries that do not have the over-enrollment bulge and which essentially enroll $100 \%$ of their children, spend only about 38\% (see Crouch and Merseth 2017, p. 189). This level of funding for primary school, in turn, decreases funding for preprimary and for secondary education. This situation has also contributed to large class sizes: 62 in grades 1 and 2 on average, although it can often exceed 100 children in areas of high population density. Also, more than $67 \%$ of grade 1 cohorts are double-shifting (in some cases with two different teachers for the two children's groups, in some cases with the same teacher), because of high enrollment in existing classrooms. Teachers frequently talk about problems in managing such big classes, particularly, because a large proportion of grade 1 children are socio-emotionally and academically not ready to engage with learning in large classes.

Repetition is common in the Burundi education system, especially in the foundation grades. Further, the official rate of repetition in grade 1 may be undercounting the total (official and unofficial) percent rate by around 13 points (see Crouch et al. 2020). The high rate of repeaters directly leads to crowded classes and low levels of learning. Official and unofficial repeats are, to a degree, caused by poor practices of classroom management, and perhaps because parents use of grade 1 in lieu of preprimary Non-identification of weaker students also may play a role.

Burundi is more and more cognizant of these challenges and is taking action. For example, as part of the Burundi Early Grade Learning Project (BEGLP), the Ministry of General, Vocational, and Technical Education is developing new learning materials aimed at improving reading fluency, in particular, in the foundation grades. Through a project of the Global Partnership for Education, new schools and new classrooms will reduce class sizes and double shifts. More specifically, it is an objective of the Ministry to ensure that, by 2022, all 5-year-olds have access to at least one year of quality preschool. It plans to construct and staff 2016 new preschool classrooms in existing schools. All new schools will be required to also build at least one classroom for preschool. Unfortunately, insufficient finance has so far somewhat hampered implementation. 


\section{Ethiopia}

Ethiopia undertook tremendous gains in enrollment in basic education (grades 1 through 12) over the past two decades. Enrollment in basic education ballooned almost threefold from 8.1 million in 2000-2001 to 22.9 million in 2018-2019, with 20.1 million in primary school and 2.8 million in secondary education. Preschool enrollment increased from 110,000 students (ages 4-6) to 3.2 million during the same period. In part, as a result of this surge, problems of student flow through to primary school completion persist. The issues, as discussed elsewhere in this paper, include high repetition rates in grade 1 , over-enrollment in grades 1 and 2, dropout by grade 5 , and consistently low completion rates at grade 5 . The low internal efficiency in the system has remained similar for the past two decades. In addition, the completion rate at grade 7 has stayed around 55\% since about 2010. This means that Ethiopia makes about 35\% more enrollment effort than it should, for each child who completes primary school (see Table 1 in Crouch et al. 2020). As also mentioned in that paper, a relatively low official repetition rate in grade 1 is probably a large underestimation and may be due to inaccurate data collection at the school level, or a conceptual gap between theoretical definitions of repetition and reality in Ethiopia.

The issues of internal efficiency are addressed by the General Education Quality Improvement Program for Equity (GEQIP-E), which is a large Ministry program funded by several development agencies. The program targets the issues of low promotion rates from grades 1 to 2 , as well as low completion of grade 5 as important barriers to ensuring that more children will complete primary school. Through policy dialogues between the Ministry and development agencies, as well as rigorous international literature reviews (Bashir et al. 2018), the country is putting more emphasis on growth and quality improvements in early childhood as another way of addressing the flow inefficiencies through primary school.

\section{Madagascar}

Madagascar has the next-to-lowest progression in the foundation years according to early grade "bulge index" rankings reported by Bashir et al. (2018), after Rwanda. This implies children are "churning in the early grades, attending infrequently, repeating grades and eventually leaving the education system with few cognitive skills" (Bashir et al. 2018, p. 147). Between-grade progression remains a significant constraint in the education system, leading to a great deal of waste of potential human capital and public funds. The challenge comes partly from rapid increases in the number of children enrolled. This growth is stressing the education system's ability to stay afloat. In the foundation years, there are also a few related and negatively synergistic problems: (a) bulged enrollments, particularly in grade 1, with a lot of too-young and too-old children creating age heterogeneity; (b) teachers with low subject and teaching skills, even for early grade mathematics and reading; (c) teaching time that is insufficient, as well as many teacher and school leader absences; (d) early moves from mother tongue to French as the teaching language; 
(e) poor learning conditions; and (f) preprimary coverage that is insufficient in both amount and quality.

In the past 10 years or so, Madagascar's government has made a big effort to improve enrollment and entry into primary schools. Since approximately 2008, the gross enrollment rate for primary school has hovered around $140 \%$ or more. Simultaneously, the completion rate in primary school went down from about $74 \%$ in 2009 to about $65 \%$ in 2018 . High repeat counts, reported officially, are likely very much lower than the high level of unofficial repetition actually happening in the foundation grades of schools. Enrollment of many under-age and over-age children, bulged up the early grades, creates age heterogeneity. The bulge is largely due to repetition, though, rather than too-young or too-early enrollment, though that is a problem in and of itself because it also adds to the age heterogeneity. Preschool supports emergence of reading, and grade 1 preparation. Yet, as few as $39 \%$ of appropriately aged children attend preprimary, using 2018 UIS data. There is in addition a large inequality between regions and classes in opportunities for preprimary-much more so than for primary.

\section{Conclusions and Policy Implications}

This paper has described a pattern of symptoms affecting early years education, through preprimary programs to year 2 of school, which coalesce into a consistent syndrome, across countries, documented in Crouch and Merseth (2017) and Bashir et al. (2018). The syndrome is characterized by four variables: lack of access to quality preprimary; permanently high apparent (but logically impossible) intakes into grade 1 each year; grade 1 over-enrollment; and large apparent drop-off between grades 1 and 2. King et al. (2020) found that global indicators preprimary overestimate preprimary enrollment because under-age children attending grade 1 are being counted as enrolled in preprimary when they are in fact not. Thus, the situation has not improved as much as the globally-tracked data would suggest, and the lack of preprimary continued to be a major part of the weak foundations syndrome.

The symptoms are robust enough and coherent enough, across low- and middleincome countries to suggest deeper causes. Increased access to quality preprimary and preprimary programs would alleviate the burden of over-enrollment in grade 1, through two mechanisms: (1) By reducing enrollment of under-age children who attend grade 1 in lieu of preprimary classes; and (2) Providing increased opportunities to improve children's academic and social-emotional skills, as preprimary education programs have done in Ghana, Kenya, Mozambique and Tanzania, among others (see Martinez et al. 2012; Mwauraa et al. 2008; Ngware et al. 2018; Wolf et al. 2018). The second deeper cause of the syndrome implied by the data is as difficult to address as it is easy to say: the quality of education in early primary grades must be improved. The relationship documented here between the weak early foundations syndrome and low primary completion rates supports the Cunha and Heckman (2007) skill-building model of human development, in which not only does early skill acquisition beget later skill acquisition, but skills acquired prior to an investment in human capital will increase the later effectiveness of that investment 
(see Bailey et al. 2017 for a discussion of skill-building conceptual frameworks). In this way, attendance in preprimary programs could both alleviate the overcrowding in grade 1, while also equipping children with skills that will help them excel in grade 1 and then making investment in grade 1 more productive.

This paper adds support to the literature (including influential institutional reports such as Bashir et al. 2018) calling for major efforts to improve the quality of early education, in preprimary and early primary grades. There is no magic bullet, but some ideas include reforming early education administrative structures to operate as a continuum bridging preprimary and primary. At the central level of Ministries of Education, as well as in schools, preprimary and early primary grades need to be coordinated and aligned in instructional practices, curricular content, social norms, and expectations. Steps need to be taken at the school and community level to ensure that children enroll on time, in the appropriate grade for their age, in tandem with efforts to expand access to preprimary (including private and community-based options). Long-standing challenges related to teacher professional development, availability of teaching and learning materials in mother tongue, and appropriate screening and support services for children with developmental delays and disabilities must be addressed urgently.

At the same time, one has to admit that simply adding another year to the beginning of education systems, without addressing quality issues, will not be of much help. In fact, raw historical data from Latin America and South Africa, available in online databases, ${ }^{4}$ reveal that, at least at first, the addition of a preprimary year seems to at least partially displace downward the grade 1 over-enrollment bulge and inappropriate use of early entry into formal school in lieu of preprimary. Yoshikawa et al. $(2018$, p. 1$)$ caution that while “... investment in ECD has expanded worldwide ... with these increased investments comes evidence that the capacity of policy systems to support ECD across health, education, social protection, and other sectors is weak, with unfulfilled developmental potential a serious consequence within and across countries."

One of the most promising threads of this research relates to the data showing parents' support for preschool by enrolling their children early in grade 1. It strikes us that this parental commitment to early education can be capitalized to increase accountability for school performance in the early grades. As the weak foundations syndrome reflects a pattern of symptoms, so solutions cannot be found through any simple, single option. Multiple strategies are required in response. The ideas presented in this paper and other research aiming to improve quality in early years education must be taken up by governments in a concerted, sustained effort to correct system inefficiencies and unlock the potential of the next generation.

Open Access This article is licensed under a Creative Commons Attribution 4.0 International License, which permits use, sharing, adaptation, distribution and reproduction in any medium or format, as long as you give appropriate credit to the original author(s) and the source, provide a link to the Creative Commons licence, and indicate if changes were made. The images or other third party material in this

\footnotetext{
4 Such data can be accessed from World Bank databank: https://databank.worldbank.org/repor ts.aspx ? source $=$ Education $\% 20$ Statistics.
} 
article are included in the article's Creative Commons licence, unless indicated otherwise in a credit line to the material. If material is not included in the article's Creative Commons licence and your intended use is not permitted by statutory regulation or exceeds the permitted use, you will need to obtain permission directly from the copyright holder. To view a copy of this licence, visit http://creativecommons.org/ licenses/by/4.0/.

\section{References}

Amadio, M. (1996). Primary school repetition: A global perspective. Paris: UNESCO International Bureau of Education.

Bailey, D., Duncan, G., Odgers, C., \& Yu, W. (2017). Persistence and fadeout in the impacts of child and adolescent interventions. Journal of Research on Educational Effectiveness., 10(1), 7-39. https://doi.org/10.1080/19345747.2016.1232459.

Bashir, S., Lockheed, M., Ninan, E., \& Tan, J. P. (2018). Facing forward: Schooling for learning in Africa. Washington, DC: World Bank.

Bernard, J. M., Simon, O., \& Vianou, K. (2007). Repeating: An African school mirage. Prepared for the conference of Ministers of Education in countries sharing the French language (CONFEMEN) programme for the analysis of education systems (PASEC). Dakar, CONFEMEN Permanent Technical Secretariat.

Branson, N., Hofmeyr, C., \& Lam, D. (2013). Progress through school and the determinants of school dropout in South Africa. Development Southern Africa, 31, 106-126. https://doi. org/10.1080/0376835X.2013.853610.

Crouch, L. (1991). A simplified linear programming approach to the estimation of enrolment transition rates: Estimating rates with minimal data availability. Economics of Education Review, 10(3), 259-269. https://doi.org/10.1016/0272-7757(91)90049-U.

Crouch, L., \& Merseth, K. (2017). Stumbling at the first step: Efficiency implications of poor performance in the foundational first five years. Prospects. https://doi.org/10.1007/s11125017-9401-1.

Crouch, L., Olefir, A., Saeki, H., \& Savrimotoo, T. (2020). Déjà vu all over again? Recent evidence on early childhood and early grade repetition in developing countries. Prospects. https://doi. org/10.1007/s11125-020-09473-2.

Crouch, L., \& Vinjevold, P. (2006). South Africa: Access before quality, and what to do now? Profesorado, 10,1 .

Cuadra, E. (1991). Data collection strategies and methods for monitoring student flows. PHREE background paper series. PHREE Series 91/43. http://documents.worldbank.org/curated/pt/86749 $1468739313300 /$ pdf/multi-page.pdf.

Cunha, F., \& Heckman, J. (2007). The technology of skill formation. American Economic Review, 97(2), 31-47. https://doi.org/10.3386/w12840.

Fletcher, P., \& Ribeiro, S. C. (1989). Modeling education system performance with demographic data: An introduction to The Profluxo Model. https://goo.gl/oTYFBH.

Gargiulo, C., \& Crouch, L. (1994). Nicaragua: Schooling, repetition, dropouts. Report on a household survey. Washington: RTI International.

Gibbs, B. G., \& Heaton, T. B. (2014). Drop out from primary to secondary school in Mexico: A life course perspective. International Journal of Educational Development, 36, 63-71. https://doi. org/10.1016/j.ijedudev.2013.11.005.

Global Partnership for Education. (2012). Results report 2012. Washington, DC: Global Partnership for Education.

Gove, A., Chabbott, C., Dick, A., DeStefano, J., King, S., Mejia, J., et al. (2015). Early learning assessments: A retrospective. Background paper for education for all global monitoring report 2015. Paris: UNESCO.

King, K., Crouch, L., Wils, A., \& Baum, D. (2020). How well are we measuring access to early childhood education? In A. Wiseman (Ed.), Annual review of international and comparative education. Bingley: Emerald Publishing.

Klein, R., \& Costa, S. (1991). O censo educational e o modelo de fluxo: O problema da repetencia [The education census and the flow model: The problem of repetition]. Revista Brasileira de Estatística, 57(197), 5-45. 
Le Nestour, A., \& Sandefur, J. (2020). Africa's literacy boom, 1940-2000. Unpublished manuscript. Washington, D. C.: Center for Global Development.

Martinez, S., Naudeau, S., \& Pereira, V. (2012). The promise of preschool in Africa: A randomized impact evaluation of early childhood development in Rural Mozambique. International Initiative for Impact Evaluation (3ie). https://www.3ieimpact.org/sites/default/files/2017-11/3ie_mozam bique_ie001.pdf.

Mwauraa, P. A. M., Sylvab, K., \& Malmbergb, L.-E. (2008). Evaluating the Madrasa preschool programme in East Africa: A quasi-experimental study. International Journal of Early Years Education, 16(3), 237-255.

N'tchougan-Sonou, C. H. (2001). Automatic promotion or large-scale repetition-Which path to quality? International Journal of Educational Development, 21, 149-162. https://doi.org/10.1016/s0738 -0593(00)00016-x.

Ngware, M., Hungi, N., Wekulo, P., Mutisya, M., Njagi, J., Muhia, N., Wambiya, E., Donfouet, H., Gathoni, G., \& Mambe, S. (2018). Impact evaluation of Tayari school readiness program in Kenya. African Population and Health Research Centre, RTI International, and Children's Investment Fund Foundation. https://aphrc.org/wp-content/uploads/2019/07/Impact_Evaluation_ECDE_Tayari-longreport.pdf.

Randall, L., \& Anderson, J. (2015). Schooling for success: Preventing repetition and dropout in Latin American primary schools. New York: Routledge.

Ribeiro, S. C. (1991). A pedagogia da repetência. Estudos Avançados, 5, 07-21. https://doi.org/10.1590/ s0103-40141991000200002.

Sabates, R., Hossain, A., \& Lewin, K. M. (2013). School drop out in Bangladesh: Insights using panel data. International Journal of Educational Development, 33, 225-232. https://doi.org/10.1016/j. ijedudev.2012.09.007.

Schiefelbein, E. (1975). Repeating: An overlooked problem of Latin American education. Comparative Education Review, 19, 468-487.

Schiefelbein, E., \& Wolff, L. (1993). Repetition and inadequate achievement in primary schools in Latin America: Magnitudes, causes, relationships and strategies. Santiago: UNESCO Bulletin of the Principal Project in Education.

Smith, M. L. (1989). Teachers' beliefs about retention. In L. A. Shepard \& M. L. Smith (Eds.), Flunking grades: Research and policies on retention (pp. 132-150). London: Falmer Press.

Taylor, S., \& Spaull, N. (2015). Measuring access to learning over a period of increased access to schooling: The case of Southern and Eastern Africa since 2000. International Journal of Educational Development, 41, 47-59.

UNESCO. IIEP. (2006). Repetition. Policy Series No. 6. Paris: UNESCO https://unesdoc.unesco.org/ ark:/48223/pf0000152038.

United Nations, Economic and Social Council. (2016). Report of the inter agency and expert group on sustainable development goal indicators. E/CN.3/2016/2/Rev.1*.

Weatherholt, T., Jordan, R., Crouch, L., Barnett, E., \& Pressley, J. (2019). Challenge and drivers of overenrolment in the early years of primary school in Uganda. International Journal of Early Childhood, 51, 23-40. https://doi.org/10.1007/s13158-019-00238-3.

Wolf, S., Razab, M., Kim, S., Aberb, J. L., Behrman, J., \& Seidman, E. (2018). Measuring and predicting process quality in Ghanaian pre-primary classrooms using the Teacher Instructional Practices and Processes System (TIPPS). Early Childhood Research Quarterly, 45, 18-30. https://doi. org/10.1016/j.ecresq.2018.05.003.

World Bank. (2019). Ending learning poverty: What will it take? Conference version. Washington, D.C.: World Bank.

Yoshikawa, H., Wuermli, A., Raikes, A., Kim, S., \& Kabay, S. (2018). Toward high-quality early childhood development programs and policies at national scale: Directions for research in global contexts. Social Policy Report, 31(1), 1-36.

Publisher's Note Springer Nature remains neutral with regard to jurisdictional claims in published maps and institutional affiliations. 